\title{
Arquitetura Islâmica: a construção das mesquitas como instrumento legitimador da fé
}

\author{
Islamic Architecture: the construction of mosques as a legitimating instrument of the faith \\ Arquitectura Islámica: la construcción de las mezquitas como instrumento legitimador de la fe
}

Recebido: 11/10/2021 | Revisado: 19/10/2021 | Aceito: 21/10/2021 | Publicado: 23/10/2021

Gabrielle Soares de Morais Leite
ORCID: https://orcid.org/0000-0002-3593-4853
Faculdades Santo Agostinho, Brasil
E-mail: gabriellesmk@ gmail.com
Soraya Mattos Pretti
ORCID: https://orcid.org/0000-0002-9835-7635
Faculdades Santo Agostinho, Brasil
E-mail: soraya.mattos@ fasa.edu.br

\begin{abstract}
Resumo
O presente estudo tem como objetivo analisar a influência da religião na arquitetura islâmica, considerando que a fé é o cerne de toda a vida dos muçulmanos e a arquitetura é utilizada como um meio para alcançar os seus preceitos. A mesquita é o edifício "símbolo" que marca a paisagem das cidades, ponto do qual inicia o seu desenvolvimento. Objetiva-se, também, esclarecer a diferença entre árabes e muçulmanos, e oferecer material sobre sua cultura, que é tão desconhecida em nosso país. A metodologia utilizada foi investigação bibliográfica exploratória, com abordagem qualitativa e aplicação do método hipotético-dedutivo, de modo descritivo. Os resultados alcançados apontam no sentido de que a arquitetura para o islamismo transcende o meio físico e os significado a que estamos habituados como obra de arte, celebração da humanidade, edificação e abrigo, e passa a ter o papel de ser canal para o cumprimento das determinações das Sagradas Escrituras, trazendo as conexões sagradas para perto dos homens. Conclui-se, portanto, que a arquitetura e o urbanismo são amplamente influenciados pela religião, e essa influência determinam os elementos marcantes dessa arquitetura, que são passíveis de serem visto na arquitetura leiga desses povos, bem como na de outros pela grande expansão/ atuação que a cultura árabe possui.
\end{abstract}

Palavras-chave: Arquitetura; Islamismo; Mesquita.

\begin{abstract}
This study aims to analyze the influence of religion on Islamic architecture, considering that faith is the core of Muslims' entire life and architecture is used as a means to achieve its precepts. The mosque is the "symbol" building that marks the landscape of cities, the point from which its development begins. It also aims to clarify the difference between Arabs and Muslims, and offer material about their culture, which is so unknown in our country. The methodology used was exploratory bibliographic research, with a qualitative approach and application of the hypothetical-deductive method, in a descriptive way. The results achieved indicate that architecture for Islam transcends the physical environment and the meaning we are used to - as a work of art, celebration of humanity, building and shelter, and takes on the role of being a channel for fulfillment of the determinations of the Holy Scriptures, bringing the sacred connections close to men. It is concluded, therefore, that architecture and urbanism are largely influenced by religion, and this influence determines the striking elements of this architecture, which are likely to be seen in the lay architecture of these peoples, as well as in others due to the great expansion/performance that Arab culture possesses.
\end{abstract}

Keywords: Architecture; Islam; Mosque.

\section{Resumen}

Este estudio tiene como objetivo analizar la influencia de la religión en la arquitectura islámica, considerando que la fe es el núcleo de toda la vida de los musulmanes y la arquitectura se utiliza como un medio para lograr sus preceptos. La mezquita es el edificio "símbolo" que marca el paisaje de las ciudades, el punto desde donde comienza su desarrollo. También pretende aclarar la diferencia entre árabes y musulmanes, y ofrecer material sobre su cultura, tan desconocida en nuestro país. La metodología utilizada fue la investigación bibliográfica exploratoria, con enfoque cualitativo y aplicación del método hipotético-deductivo, de forma descriptiva. Los resultados alcanzados indican que la arquitectura para el Islam trasciende el entorno físico y el significado al que estamos acostumbrados - como obra de arte, celebración de la humanidad, construcción y cobijo, y asume el papel de canal para el cumplimiento de las determinaciones de la sociedad. Sagradas Escrituras, acercando las conexiones sagradas a los hombres. Se concluye, por tanto, que la arquitectura y el urbanismo están liderados por la religión, y esta influencia determina los elementos 
llamativos de esta arquitectura, que es probable que se vean en la arquitectura laica de estas personas, así como en otras debido a la gran expansión. / performance que posee la cultura árabe.

Palabras clave: Arquitectura; Islam; Mezquita.

\section{Introdução}

A palavra arquitetura deriva do grego “Arkhitekton” - “Arkhein” (comandar) e "Tekton” (artesão/construtor), podendo ser traduzida como "mestre de obras" (Gramática Net, 2020). É um produto cultural que muda conforme a evolução da sociedade, atendendo a seus anseios políticos, econômicos, estéticos, sociais e morais em determinado período de tempo.

A arquitetura árabe é gênero que contempla a arquitetura islâmica, que possui um papel central na vida de seus fiéis, os muçulmanos, e é responsável por regular não só a fé, mas grande parte da vida civil destas nações. Segundo a edição de bolso de $O$ Alcorão, o livro sagrado “contém o código religioso, moral e político dos muçulmanos” (Maomé, 2018, p.1).

O islamismo é a segunda maior religião do planeta com 1,8 bilhão de fiéis, o que corresponde a $24 \%$ da população mundial. Segundo a Pew Research Center, o maior centro de pesquisas americano, a religião islâmica irá ultrapassar os cristãos até o final do século, alcançando a marca de 3 bilhões de seguidores (Novelo, 2017).

A disseminação do islamismo no cenário mundial e nos diversos conflitos culturais que vem ocorrendo entre os ocidentais e os muçulmanos, torna extremamente importante a melhor compreensão dessa cultura, proporcionando um olhar mais humano para o outro, com maior compreensão de sua visão de mundo e maior respeito das diferenças. Neste sentido é o pensamento do filósofo Tzvetan Todorov acerca do relativismo cultural:

[...] Ter uma cultura é condição necessária para o processo de civilização: sem um mínimo de domínio de determinado código cultural, o indivíduo é condenado ao isolamento e ao silencio, portanto, à ruptura com o resto da humanidade...A recusa de considerar visões do mundo diferentes da nossa separa-nos da universalidade humana e mantém-nos mais perto do polo da barbárie. Em compensação, progredimos na civilização ao aceitarmos ver que os representantes de outras culturas têm uma humanidade semelhante à nossa... Levar em consideração o ponto de vista dos outros não significa uma opção pelo altruísmo em detrimento ao egoísmo, ou pela xenofilia contra a xenofobia: temos todo o interesse de enriquecer, assim, nossa compreensão do mundo (Todorov, 2010, p.46).

Diante desse contexto o problema de pesquisa a ser enfrentado neste trabalho é estabelecer a influência da religião na arquitetura islâmica, em especial na configuração das mesquitas. Isso porque a religião tem um papel central em toda a vida dos muçulmanos. O Alcorão e seus desdobramentos são o código religioso, moral e político, que regula inclusive as edificações daquela sociedade. A fé determina questões como a orientação espacial, o tipo de piso e de decoração, vestimentas permitidas, tendo grande influência nas edificações, em especial, na configuração das mesquitas, principal edifício daquela cultura, tornando a sua arquitetura também um instrumento para cumprir os preceitos da religião.

A partir desta problemática, definiu-se como objetivo do estudo descrever as principais características da arquitetura islâmica nas mesquitas, de forma a estabelecer sua relação com a cultura.

\section{Metodologia}

A metodologia busca otimizar o raciocínio para promover uma pesquisa eficaz que conduza aos objetivos pretendidos. Esta pesquisa configura-se por meio de uma investigação bibliográfica exploratória (Gil, 2009), visto que busca descrever o papel da religião na arquitetura muçulmana em especial nas mesquitas; explorar a cultura islâmica e compreender o modo de vida daquelas pessoas.

A abordagem, seguindo a classificação de Minayo (2008), será qualitativa pois tenta compreender os fenômenos e atribuir-lhes significados, através da interpretação subjetiva dos dados coletados para formação de uma consciência acerca do 
tema. A pesquisa será feita de modo descritivo pois não objetiva provar teses ou teorias, se limita a compreender e descrever a realidade apresentada e as características existentes nas mesquitas (Gil, 2009).

O método aplicado será o hipotético-dedutivo, pois visa estabelecer conexões que expliquem a arquitetura como fenômeno cultural, da mesma forma que a religião o é, e emitir juízos de valor que corroborem este raciocínio. Em termos de procedimento será usado o bibliográfico-narrativo, através da interpretação dos dados coletados em pesquisa bibliográfica de artigos e textos que versam sobre o tema e da leitura do Alcorão, o texto base da religião muçulmana.

Serão analisados cada um dos elementos arquitetônicos básicos de uma mesquita, bem como os elementos decorativos essenciais, através da descrição de suas características e de imagens ilustrativas.

\section{Resultados e Discussão}

A religião sempre teve um papel importante na vida dos seres humanos. Desde os tempos mais remotos, vemos a busca por conexão com uma energia superior, algo que dê sentido à existência terrena. A arquitetura é um reflexo dos acontecimentos sociais e, por isso, acompanha este pensamento. Jonathan Glancey afirma que "As primeiras obras realmente arquitetônicas são os templos. Desde a Idade do Bronze (...), a humanidade tentou ligar-se ao eterno e construir em harmonia com o cosmo" (2001, p.09).

Os povos árabes eram nômades e viviam em tribos em um território com um milhão de quilômetros quadrados em um grande deserto, com economia do pastoreio e do comércio, sem um estado centralizado. Somente após Maomé receber as revelações do anjo Gabriel no século VII, que afirmavam a existência de um Deus único, houve a unificação das tribos e a criação de uma identidade entre essas pessoas através da religião (Valjalo, 2015). Atualmente o islamismo é uma das três religiões monoteístas do mundo, com previsão de ser a maior em número de fiéis ainda neste século (Novelo, 2017), conforme pode ser observado na Figura 1.

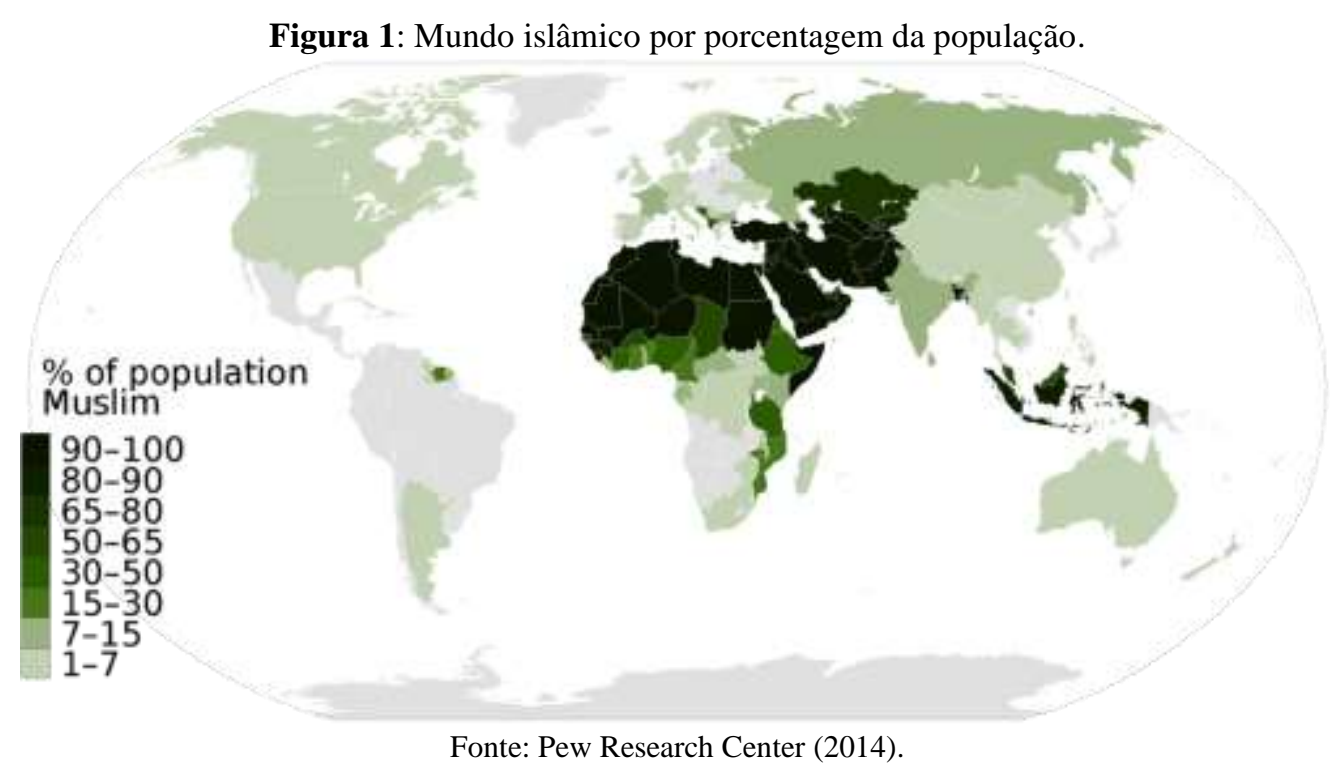

Na Figura 1 observa-se o percentual de população islâmica nos países e continentes. Possui maior prevalência no Oriente Médio, norte da África e Ásia; tendo representatividade em todos os continentes, com menor expressividade na América Latina, Groenlândia, sul da África, Europa Ocidental e Ilhas do Pacífico

Com tamanha expressividade, faz-se necessário conhecer sua cultura para se manter atualizado em um mundo globalizado. A cultura de um povo "diz respeito a tudo aquilo que caracteriza a existência social de um grupo ou nação" 
(Santos, 2006), o que inclui, portanto, a arquitetura. Para os muçulmanos, residentes em Estados teocráticos ou seculares, o eixo central de suas vidas é marcado por normas religiosas, que refletem inclusive na arquitetura, que será explorada no presente artigo através da análise das mesquitas.

A influência dos muçulmanos no mundo ocidental é antiga e contempla diversas áreas do saber. Com a expansão árabe que ocorreu entre os séculos XII e XIII (Icarabe, 2021), os muçulmanos tiveram contato com diversas culturas, como os persas, otomanos, mouriscos, indo-islâmicos, malaios, indonésios, europeus entre outros, com as quais conviveram em harmonia, trocaram conhecimentos, e contribuíram para a evolução destas sociedades. Na região da Península Ibérica, compartilharam conhecimento científico sobre matemática, filosofia, álgebra, medicina, astronomia, aritmética, sistema de numeração arábico, sendo os responsáveis por traduzir a doutrina grega e o conhecimento sobre a Terra ser esférica.

Trouxeram novas técnicas agrícolas, como a moagem de roda vertical, novas espécies vegetais e frutíferas e de irrigação, o que acabou por substituir o trabalho escravo por trabalho mecânico. Inseriram novos hábitos alimentares, segundo as regras descritas no Alcorão e novas ideias educacionais, pois diversos tratados árabes foram traduzidos para o latim. Instrumentos musicais como violino, guitarra, alaúde, gaita são derivados de instrumentos árabes. Isso sem falar na arte e na arquitetura que sofreram enorme influência, como na azulejaria, as filigranas (joalheria que representa a história, presente em Portugal), abóbodas, arcos. Também se vislumbra grande influência no vocabulário português, com cerca de 800 a 1000 palavras com destaque para aquelas com o prefixo al. Os muçulmanos tinham grande tradição na fabricação de embarcações e no desbravamento dos mares e até mesmo a palavra caravela tem origem árabe (qarib) e é semelhante ao papagaio usado por eles no Oceano Índico (Valjalo, 2015).

Assim, dada as particularidades dos muçulmanos, ao debruçar-se sobre o estudo das mesquitas, com toda sua simbologia e com seus atributos, seja como a principal edificação daquela cultura, seja por trazer todos os elementos decorativos permitidos ou por ter um papel centralizador na vida de cada um de seus fiéis, dispõe-se de material fértil para o entendimento de sua cultura e o estudo da arquitetura - que também é uma manifestação cultural.

\subsection{O mundo árabe}

O mundo árabe pode ser entendido como o conjunto de países que compartilham a cultura árabe, suas tradições, língua, alimentação, etc. A Figura 2 demonstra, geograficamente, a forma como estão dispostos:

Figura 2: Países do Mundo Árabe.

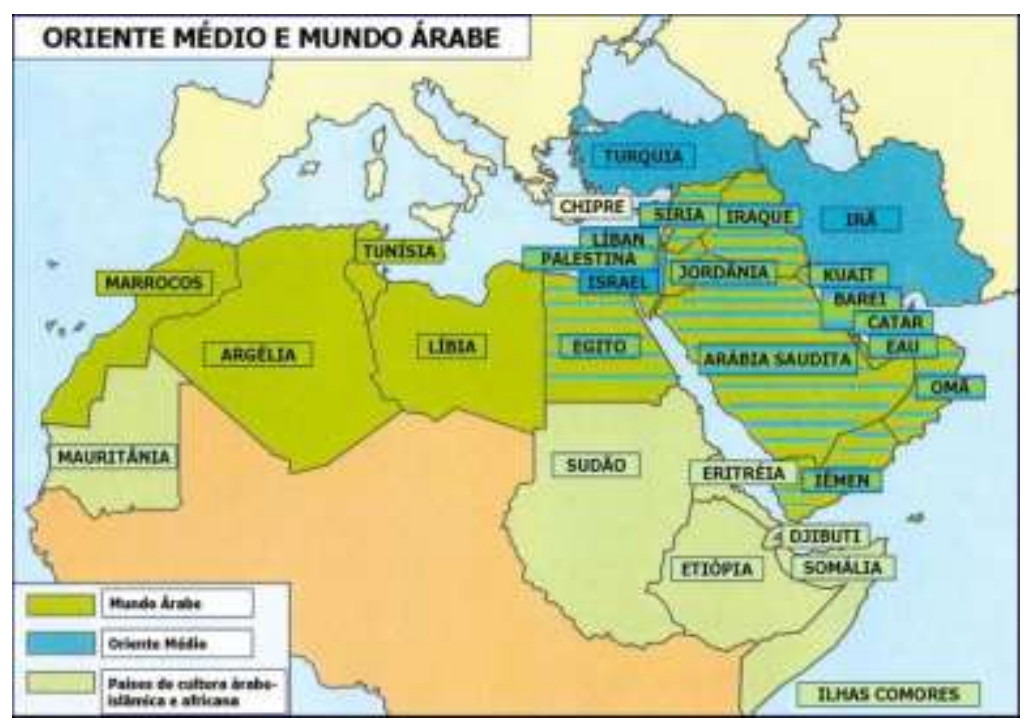

Fonte: Toda Matéria (2021). 
Como pode ser observado na Figura 2, geograficamente os países do mundo árabe estão localizados entre o Oriente Médio, a África Setentrional e a Ásia Ocidental e é composto por 22 países: Arábia Saudita, Argélia, Barein, Catar, Comores, Djibuti, Egito, Emirados Árabes Unidos, Iêmen, Iraque, Jordânia, Kuwait, Líbano, Líbia, Mauritânia, Marrocos, Omã, Palestina, Somália, Sudão, Síria e Tunísia. Alguns países com maioria muçulmana não fazem parte dessa lista, como o caso do Irã e da Turquia.

Outros países como o caso da Índia, que possui uma enorme população muçulmana, com cerca de 200 milhões de fiéis (Estado de Minas, 2020) são relevantes para a cultura islâmica, mas também não fazem parte do Mundo Árabe; porém como será apresentado a seguir os conceitos de árabe e muçulmano não se confundem.

Apesar de muitas vezes serem tratados como sinônimo há diferenças entre árabes e muçulmanos que merecem ser elucidadas. Os povos árabes são descendentes dos povos que viviam na região da Península Arábica, beduínos que viviam como nômades no deserto, e compartilhavam a adoração a deuses politeístas, o pastoreio de animais e o comércio, que foram unificados através da religião islâmica após as revelações recebidas pelo profeta Maomé no ano de 610, em Meca. O último profeta, segundo o islamismo, era filho de comerciantes, analfabeto, muito comunicativo, que teve contato com pessoas de diversas culturas e que recebeu uma revelação do anjo Gabriel aos 40 anos de idade, que lhe passou as diretrizes da nova religião, que acabou por unir o povo árabe num ideal religioso, que se tornou um Império e que irá alcançar o posto de maior religião ainda neste século (Araújo, 2019).

Árabe é um conceito relacionado a etnia, à ideia de povo, não sendo um conceito ligado necessariamente a religião. Os árabes podem ser islâmicos, cristãos, judeus ou professar ainda outra fé. É certo que a maioria dos árabes acreditam no islamismo (vide Figura 1), mas este vínculo não é relevante para este conceito. Já muçulmano sim é um conceito ligado a religião. Para uma pessoa ser considerada muçulmana é necessário que professe a fé no islamismo, independentemente de onde tenha nascido ou de sua ancestralidade. Assim, árabe é aquele que possui vínculo geográfico e cultural com os países do mundo árabe, independentemente de sua religião e muçulmano é aquela pessoa que acredita em Alá como único Deus e que pratica os preceitos revelados no Alcorão.

\subsection{Arquitetura e cultura}

A arquitetura e a cultura são fenômenos humanos que caminham de mãos dadas e muitas vezes se confundem, pois um é a tradução do outro. Defini-los não é tarefa fácil e nem mesmo os autores chegam a um consenso.

Primeiramente é preciso analisar o conceito de arquitetura. Há diversos sentidos em que este conceito pode ser explorado, desde o sentido físico, de construção, passando pelo sentido da beleza, como pelo aspecto sociológico, político, etc.

Jonathan Glancey faz um contraponto entre arquitetura e construção, dizendo que até mesmo os animais são capazes de construir abrigos, e que há uma diferença entre construção e arquitetura.

Esta, grosso modo, é a ciência e a arte de construir, ou, sendo mais poético, o momento em que um edifício é imbuído de uma magia sábia que o transforma de mero abrigo em obra de arte consciente de si. Essa arte pode tanto ofender e confundir, como deleitar. Ela mapeia nossas ambições em três dimensões sólidas. É o maior meio visível de celebrar nossa riqueza e saúde (...) e uma forma de escada para o céu" (Glancey, 2000, p.09).

Já o arquiteto Bjarke Ingels traz a seguinte definição “A arquitetura é a arte e a ciência de garantir que nossas cidades e edifícios se encaixem na maneira como queremos viver nossas vidas: o processo de manifestar nossa sociedade em nosso mundo físico" (Baratto, 2016). 
Jay A. Pritzker, no discurso de abertura do Prêmio Pritzker em 1985, fez o seguinte raciocínio: "A arquitetura pretende transcender a simples necessidade de abrigo e segurança, tornando-se uma expressão de arte" (Baratto, 2016). Frank Gehry também no discurso de abertura do Prêmio Pritzker, desta vez em 1989 a conceitua assim:

A arquitetura é um pequeno pedaço dessa equação humana, mas para os que, como nós, a praticamos, acreditamos em seu potencial para fazer a diferença, para iluminar e enriquecer a experiência humana, para enfrentar as barreiras do mal-entendido e proporcionar um belo contexto para a vida (Baratto, 2016).

Assim, entende-se que a arquitetura é o ato consciente de se produzir uma obra que está imbuída de arte e beleza, que tenha funcionalidade dentro da proposta a que foi apresentada e que seja coerente com o contexto geral da cidade em que está inserida, para que não seja uma forma desconexa e sem sentido diante o todo.

A cultura é outro assunto que pode trazer diversas conotações. José Luiz dos Santos, na obra $O$ que é cultura, afirma que "Cultura é uma preocupação contemporânea, bem viva nos tempos atuais. É uma preocupação em entender os muitos caminhos que conduziram os grupos humanos às suas relações presentes e suas perspectivas de futuro" (Santos, 2006, p.07).

Afirma que há duas concepções básicas de cultura, uma que se preocupa com a realidade social e outra que se refere ao conhecimento, que podem ser vistas a seguir:

A primeira destas concepções preocupa-se com todos os aspectos de uma realidade social. Assim, a cultura diz respeito a tudo aquilo que caracteriza a existência social de um povo ou nação ou então de grupos no interior de uma sociedade. Podemos assim falar na cultura francesa ou na cultura xavante. Do mesmo modo falamos na cultura camponesa ou então na cultura dos antigos astecas. Nesses casos, cultura refere-se a realidades sociais bem distintas.

[...] Neste caso, quando falamos em cultura estamos nos referindo mais especificamente ao conhecimento, às ideias e crenças, assim como às maneiras como eles existem na vida social. [...] O que ocorre é que há uma ênfase especial no conhecimento e dimensões associadas. Entendemos nesse caso que a cultura diz respeito a uma esfera, a um domínio da vida social. De acordo com esta segunda concepção, quando falarmos em cultura francesa poderemos estar fazendo referência à língua francesa, à sua literatura, ao conhecimento filosófico, cientifico e artístico produzidos na França e às instituições mais de perto associadas a eles (Santos, 2006, p.24).

Diante destas considerações, observa-se que a cultura pode ser entendida como aquilo que caracteriza determinado grupo de pessoas, de um local. É aquilo que dá sentido ao seu entendimento sobre o lugar que se ocupa no mundo, suas crenças, valores e necessidades, que são traduzidos através da língua, da culinária, da música, das artes como um todo, o que inclui a arquitetura.

\subsection{A evolução da sociedade e seu impacto na arquitetura}

Quando surgiu a arquitetura? A arquitetura surge quando os humanos passam da condição de caçadores-coletores e se estabelecem nas margens do Rio Nilo e na região do Crescente Fértil (que corresponde ao atual território do Egito, Israel, Iraque e Irã), começam a cultivar a agricultura e a formar cidades e civilizações, que dão origem à sociedade atual.

A primeira cidade conhecida é a de Jericó, onde foram encontradas residências, que datam de 8000 a.C. e templos que remontam a 7000 a.C, feitos de tijolos de barro e com uma configuração espacial semelhante ao urbanismo praticado hoje em dia (Glancey, 2000). Com a evolução da sociedade e o aumento populacional surgiu a figura de líderes, sacerdotes e reis, que representavam divindades e passaram a construir templos, palácios e túmulos, a unir o poder econômico, a proteger o povo e serem por eles temidos. A partir de então, a arquitetura, como um instrumento de poder, passou a servir aos interesses destas figuras de autoridade e criar um elo de ligação entre os céus, a terra e o imaginário popular. 
Nas primeiras civilizações os arquitetos buscaram alcançar o divino, a transcender a humanidade para uma energia superior, que desse sentido à própria existência através de obras arquitetônicas, como o caso das pirâmides e dos zigurartes ${ }^{1}$. Com o passar do tempo, constata-se em vários estilos arquitetônicos a manutenção desse desejo, através da presença de templos e igrejas como protagonistas, pois a religião tinha um papel relevante na sociedade, o que se refletia nas edificações.

No mundo islâmico a presença da religião é sentida de forma ainda mais intensa, isso porque alguns Estados são teocráticos, ou seja, há simbiose entre as regras religiosas e as normas de conduta e controle estatal. O Alcorão, um texto do século VII, na maior parte das vezes é fonte legislativa a regular toda a sociedade. Contudo, isso não quer dizer que não há atualização de sua interpretação, o que é feito através das escolas de jurisprudência, o que ocorre nas madrassas e em algumas mesquitas (Mariani, 2019).

\subsection{A importância das mesquitas no contexto islâmico - os vários papéis}

É certo que a religiosidade possui um papel importante na vida da maioria dos seres humanos. Até mesmo entre os ateus, há a crença em algum tipo de espiritualidade. Segundo o Censo de 2010 do IBGE, $8 \%$ dos brasileiros se declaravam sem religião; desses, $18 \%$ afirmaram ser cristãos, $1 \%$ ser budistas e $1 \%$ não souberam informar; $1 / 4$ acreditavam em reencarnação e 1/3 em vida após a morte (Viggiano, 2019). Assim entende-se que a espiritualidade pode ser vista como uma necessidade do ser humano em compreender melhor sua passagem por este mundo e lidar com a certeza da finitude, a qual estão todos fadados.

Para se entender a relevância da religião para os muçulmanos, faz-se necessário um exercício de imersão nos valores por eles praticados para compreender o panorama, fazendo um contraponto com o que se vivencia no Brasil. O Brasil é considerado um Estado secular que possui forte tradição cristã, com regras de conduta moral não coercitivas que acabam refletindo na legislação vigente, como no preâmbulo da Constituição Federal que invoca a proteção de Deus para promulgar a norma suprema do país (Brasil, 2021). Agora imagine nascer num país em que não haja separação clara entre Estado e religião, em que as normas religiosas sejam dotadas de coercitividade e que devam ser observadas por todos ${ }^{2}$; em que a principal construção, aquela que ocupa um papel central, tanto física quanto simbolicamente, seja o templo, a mesquita. Só por este pequeno raciocínio já se pode imaginar a relevância e o impacto da fé para os islâmicos.

No islamismo, no campo da arquitetura percebe-se a predominância da mesquita ${ }^{3}$ diante as demais edificações. Mariani aduz que:

[...] as cidades foram sempre constituídas em torno da maior mesquita da cidade, onde se realizavam as reuniões comunitárias e, sobretudo, as orações de sexta feira. Segundo Hak (1991), as ruas das cidades islâmicas medievais saíam para o centro da cidade, onde se encontravam elementos como a mesquita, uma fonte de água, o forno público e um hammâm. Isso, portanto, revela o fato de que a mesquita fisicamente sempre estava presente na vida de cada muçulmano, assim como hoje é na maioria dos países majoritariamente muçulmanos. Essa tese se baseia na quantidade de mesquitas que existem em cada bairro de uma cidade (Mariani, 2019, p. 137).

\footnotetext{
${ }^{1}$ Monumento em forma de pirâmide, construído em patamares superpostos, característico da arquitetura religiosa mesopotâmica, com acesso por rampas e escadarias ao topo, onde se erigia um santuário, tb. us. para a salvaguarda das provisões de cereais e para observações dos astros (Oxford Languages and Google, 2021).

${ }^{2}$ Os países majoritariamente muçulmanos são muitos e espalhados pelo mundo. Como característica de sua soberania não há um padrão em relação a ser o Estado laico ou teocrático; em alguns países aplica-se leis civis à população, em outros as normas religiosas são usadas como legislação pátria, e em outros ainda o cidadão pode escolher ser julgado por um tribunal que aplica leis religiosas ou por um tribunal laico. (Araújo, 2019). Além do Alcorão fazem parte do direito islâmico - em ordem de importância, o estudo da Suna que retrata a vida de Maomé e pode ser entendido como "o caminho" e da Sharia ${ }^{2}$, o conjunto de leis islâmicas que regula os comportamentos proibidos e permitidos e que pode ser de aplicação obrigatória ou não, a depender do Estado.

${ }^{3}$ Em árabe masjid - lugar de prostração, reza e oração (Mariani, 2019, p. 135).
} 
O Alcorão prega a obrigatoriedade de cinco orações diárias, que deve ocorrer nas mesquitas ao menos nas sextasfeiras $\left(\right.$ ( $\left.и т т u^{\prime} a^{4}\right)$, em razão do sermão e da prece coletiva e que devem ocorrem na maior mesquita da cidade, denominada de maior mesquita, mesquita de sexta-feira ou grão-mesquita. Além da função religiosa, as mesquitas assumem várias outras funções, como a função política, social e educacional (Mariani, 2019), pode ser vista também como expoente da evolução das artes islâmicas, que a adornam. A doutrina islâmica proíbe o uso da figura humana nas artes plásticas, principalmente na pintura e na escultura, para evitar a adoração de outrem, que não Alá, o que os levou a desenvolver outros tipos de arte para adornar os seus templos e catequizar os fiéis, o que será abordado adiante.

Outra função exercida nas mesquitas ao longo do tempo é a de ensino. Inicialmente os estudos científicos e jurídicos do islã, além dos estudos sobre a própria religião e a vida cotidiana ocorriam dentro das mesquitas (que tinham até bibliotecas) ou nas madrassas - edifícios que ficavam ao lado das mesquitas. Apesar de atualmente tais estudos ocorrerem em universidades, percebe-se que ainda ocorrem nas madrassas e em algumas mesquitas, que abrigam esta função.

Também se observa a função de centro político. Ao longo da história, na época de Maomé e de seus quatro primeiros sucessores, chamados de califas, a figura de Chefe de Estado e Chefe Religioso se confundiam e o local em que moravam e exerciam suas funções religiosas e políticas era a mesquita. Após os primeiros trinta anos do islã e durante o século XX os governantes passaram a residir e a governar em palácios, mas se comunicavam com as pessoas através da mesquita, o que lhes conferia maior legitimidade e foi usado como força política para manter no poder governos autoritários (Mariani, 2019). Atualmente os governantes utilizam as mesquitas para os sermões, o que gera discussões sobre o uso político dos templos por alguns fiéis.

Porém, a principal função da mesquita foi e sempre será a religiosa, de unir os crentes em um local que tenha os elementos necessários para professar sua fé, cujas artes não sejam profanas e que represente o local de devoção para a sua profissão de fé, o elemento base daquela cultura. Assim, entende-se que apesar da espiritualidade ser a principal função das mesquitas não se pode esquecer os demais usos e papéis que a ela são conferidos, que possuem enorme relevância naquela cultura.

\subsection{Elementos arquitetônicos básicos de uma mesquita}

Mesquita - masjid em árabe significa "lugar onde os homens se prostram diante de Deus" (Santos, p.50). No início da religião não havia templo, os contemporâneos de Maomé eram alvo de perseguição e faziam suas celebrações escondidos em tendas no deserto. A primeira mesquita construída é a própria casa de Maomé, em Medina, cuja planta (figura 3) serviu de modelo para as demais construções da época. A Casa do Profeta tinha diversas funções, como local de orações, de reuniões políticas, hospital e abrigo para os necessitados. Percebe-se que estas diversas funções permanecem os dias de hoje, com os edifícios adjacentes às mesquitas.

As mesquitas representam a religiosidade, a sapiência e o poder. Não são todas iguais; como o Império Árabe ocupou um vasto território tendo sofrido forte influência dos povos conquistados, a arquitetura sofre modificações quanto ao estilo, a depender do local e da época em que foram construídas. Atualmente, podemos listar como elementos arquitetônicos básicos de uma mesquita o mirabe (mihrab), púlpito $\left(m i n b a r^{5}\right)$, dikka, minarete, fonte, sala de orações (sahn), pátio externo, cúpulas (qubba) e portal (Rocco). No campo das artes percebe-se a presença de tapeçaria, arabescos e caligrafia árabe.

Às sextas-feiras, que é considerado o dia sagrado para o islamismo, é recomendado que as pessoas, em especial, os homens, se dirijam à Grande Mesquita da cidade, ao meio-dia, para a oração e escuta do sermão. Abaixo apresenta-se a figura 3 com a configuração básica de uma mesquita.

\footnotetext{
${ }^{4}$ Reunião, coletividade, sexta-feira (Mariani, 2019, p. 136).

${ }^{5}$ Minbar, em árabe, significa assento para dialogar, trono ou poltrona.
} 
Figura 3: Esquema da planta da Casa do Profeta em Medina, Arábia Saudita e Planta Básica de uma mesquita.

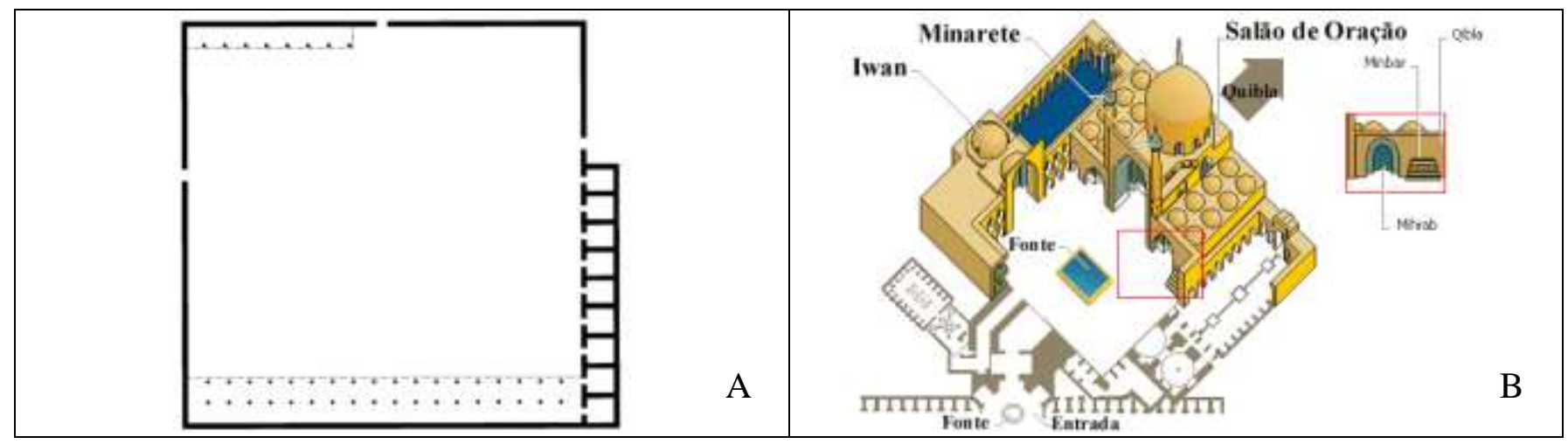

Fonte: Khanacademy (2021), e Rodrigues (2021).

A Figura 3 apresenta uma representação de como era casa de Maomé em Medina (A), local considerado a primeira mesquita construída e que atualmente abriga a Masjid na-Nabawi, o segundo local mais sagrado do Islã. "Constituía uma planta quadrangular, com pátio voltado para o sul e duas galerias com teto de palha e colunas de tronco de palmeira" (Zimmermann, 2021). Já a figura B demonstra como os elementos arquitetônicos são dispostos em uma mesquita, de forma que fique mais fácil a compreensão espacial. Percebe-se a entrada com a fonte para o ritual de ablução, seguido do pátio externo com outra fonte e a estrutura interna, com destaque para o minarete e o salão de orações com a quibla.

Mirabe é uma abertura na parede que indica a direção de Meca (Qibla), para a qual todo fiel deve se voltar durante as orações. Geralmente é um nicho ornamentado com uma cúpula acima, e os fiéis formam fileiras sequenciadas em sua direção, é a parte mais sagrada do edifício. O púlpito é mais comum de ser encontrado nas Grandes Mesquitas e consiste em uma estrutura elevada no salão de orações no qual o imãm emite o sermão de sexta-feira e fica ao lado do mirabe. A figura 4 demonstra como são utilizados o mirabe e o púlpito nas mesquitas.

Figura 4: Mirabe e Mimbar, das Mesquitas de Mesquita de Isfahan (A), Rüstem Paxa (B) e do Sultão Hassan (C).

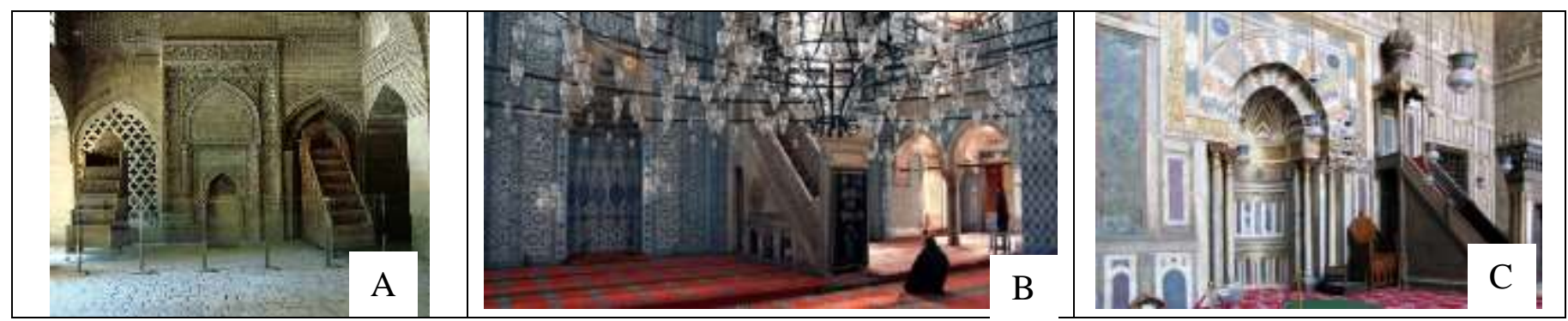

Fonte: Piccini (2021), Terra Santa Viagens (2021), Khanacademy (2021).

A Figura 4 traz três exemplos de mirabe e mimbar, de estilos diferentes, em que a decoração acompanha o estilo do local em que está inserida. Destaca-se o estilo vernacular (A), com materiais naturais e cores neutras; na Figura 4B observa-se um ambiente mais luxuoso, com o uso de azulejaria, tapeçaria e lustres, e na Figura 4C elementos característicos da cultura africana.

Outra característica das Grandes Mesquitas é a dikka, utilizada em mesquitas muito grandes nas quais os fiéis que estão mais distantes não conseguem ouvir e ver o imãm proferir o sermão com clareza, que consiste em uma estrutura de madeira de um pavimento no qual uma pessoa fica responsável por repetir os gestos e as falas do imãm para o público.

Minarete é uma torre na qual o muezim entoa um cântico (oração) chamando os fiéis para cada uma das cinco orações diárias; seu significado literal é "o ponto por onde a luz se espalha" (Mariani, p.19). Além da função religiosa o minarete 
também é considerado um elemento urbanístico, por causa de sua elevada altura, que marca a paisagem da cidade. O número de minaretes varia a depender do porte e da relação com o entorno da mesquita, bem como os formatos variados (Figura 5). Atualmente o minarete é um importante símbolo do islamismo.

A sala de orações apresenta forma retangular ou quadrada e tem alas separadas para homens e mulheres, sendo sustentada por colunas e arcos; não possui qualquer tipo de móvel, sendo coberta por tapetes, nos quais os fiéis se prostram de joelhos para adorar a Alá. A posição de oração dos muçulmanos, com a fronte tocando o chão demonstra total entrega e submissão. Todas as mesquitas devem contar com a sala de orações, porém a sala da Grande Mesquita deve ser capaz de abrigar todos os homens da cidade nas orações de sexta feira.

Apesar de geralmente estarem localizadas em locais quentes e secos, muitas vezes desérticos, percebe-se que as mesquitas possuem clima agradável e ameno, sendo circundadas por um pátio externo, que pode contar com água e vegetação, compondo a paisagem e integrando o interior e o exterior. A arquitetura e os materiais utilizados são pensados para promover o melhor aproveitamento da ventilação e iluminação natural, fatores essenciais para o conforto ambiental e facilitar a introspecção e a conexão com o divino.

O pátio externo também possui a função de abrigar os fiéis quando necessário, como ocorre na Grande Mesquita de Meca, que tem a capacidade de receber até 4 milhões de pessoas, sendo o local mais sagrado do islamismo, por conter a Caaba, um cubro preto que guarda relíquias que remontam Adão e Eva e simboliza a união entre Deus e os homens (Britannica, 2021). Todo muçulmano que tiver condições financeiras e de saúde deve fazer a peregrinação ao menos uma vez na vida. A figura 5 apresenta os elementos acima citados.

Figura 5: Dikka da Mesquita do Sultão Hassan (A), Minarete da Mesquita Azul (B), Minarete da Mesquita Kairouan (C), Minarete da Grande Mesquita de Samarra (D), Sala de Orações da Mesquita do Sheik Zayed (E), Sala de Orações da Masjid alHaram (F), Sala de Orações da Mesquita Sultan Qaboos (G), Pátio externo da Mesquita Sheik Zayed (H) e Pátio externo da Grande Mesquita de Meca (I).

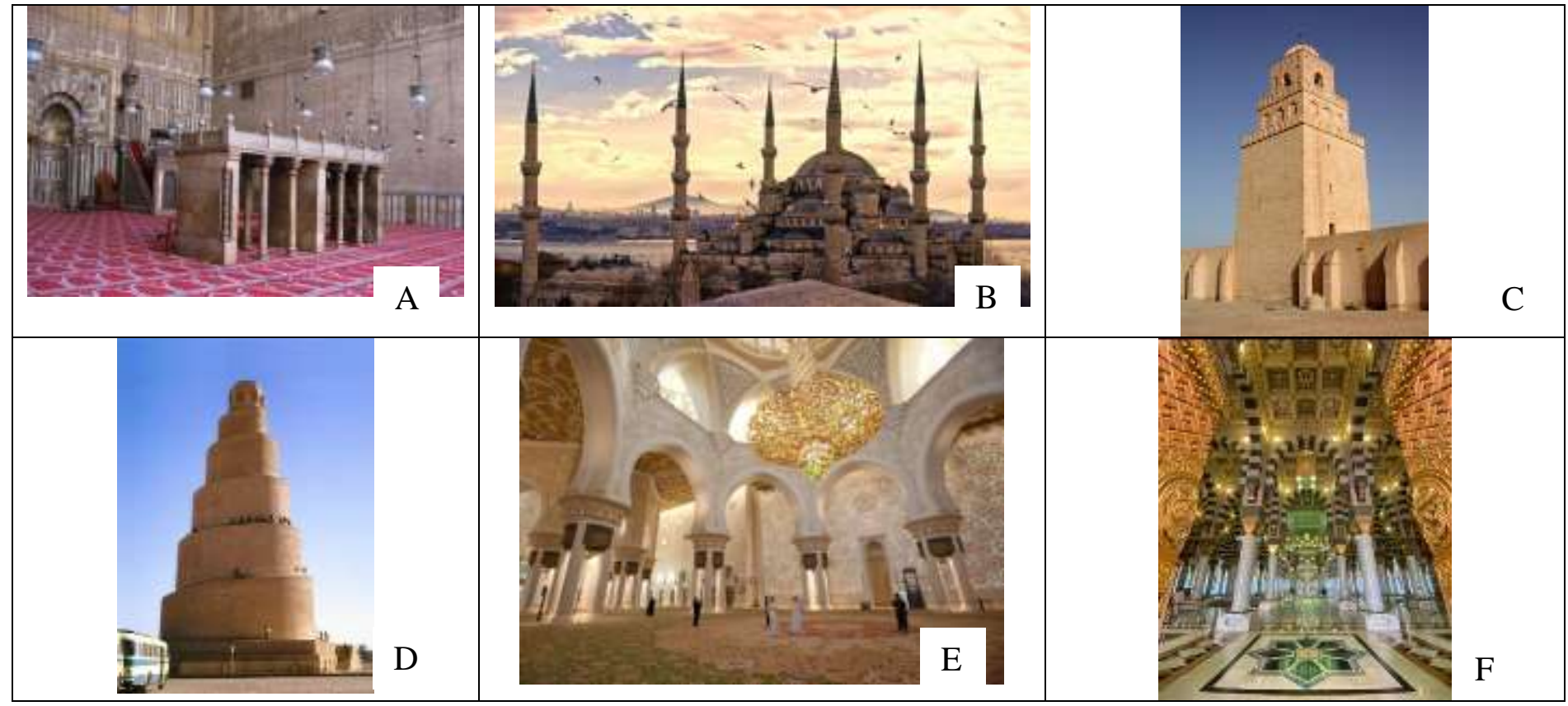




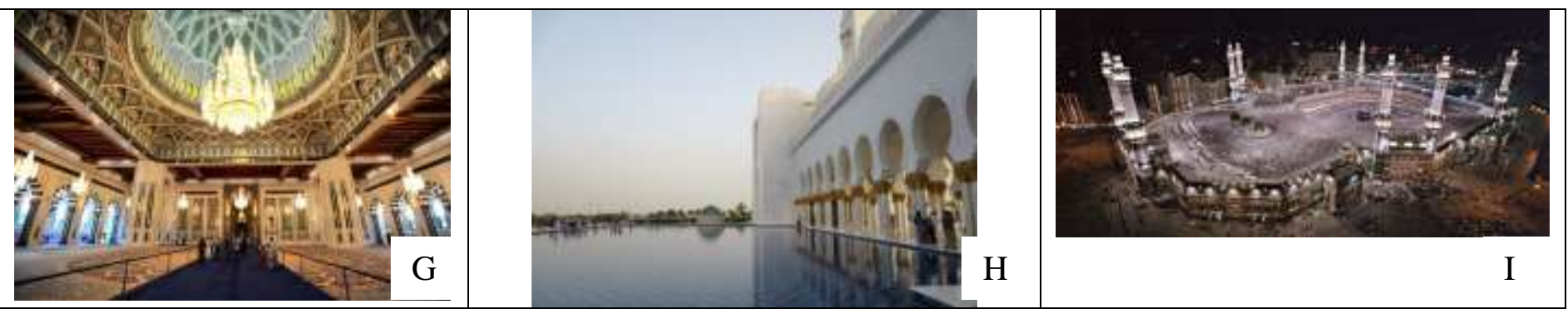

Fonte: Emotours Egypt (2021)(A), Sultanahmetcamii (2021)(B), Archdaily (2021)(C), Archdaily (2021)(D), Wikiarquitectura (2021)(E), Instagram (2021)(F), Alma de Viajante (2017)G), Wikiarquitectura (2021)(H), Epochtimes 2021(I).

Na Figura 5 pode-se observar o exemplo da dikka (A), exemplos de variados formatos de minaretes (B. C e D), salas de orações, com decorações suntuosas, presença de tapeçaria e cúpula, demonstrando o esplendor das mesquitas. Nos pátios externos há destaque para a água $(\mathrm{H})$ e para a quantidade expressiva de pessoas (I), no local mais sagrado do islamismo.

A água é um elemento muito valorizado e celebrado pelos povos do deserto, sendo muito comum encontrar edificações com pátio central e água para trazer conforto térmico. Logo, no principal edifício daquela cultura não poderia faltar o elemento essencial para a vida humana. Apesar de não ser obrigatória, é muito comum ter a fonte, que além da função ornamental, possui a função de promover a higiene, no ritual de ablução, obrigatório antes das orações (que pode ser feito com areia caso não tenha água por perto).

As cúpulas são elementos grandiosos que simbolizam o céu, tendo o seu interior ricamente ornamentado com motivos geométricos e que inspirem os fiéis. Nas mesquitas que possuem apenas uma cúpula, esta ocupa o local de maior importância e mais sagrado, acima da parede da qibla, sendo o local de maior beleza de todo o edifício.

As mesquitas podem ser edifícios patrocinados por pessoas com grande poder aquisitivo que queiram deixar um legado na sociedade ou financiadas pelo poder público. Um dos pilares da religião islâmica é a caridade e a construção de uma mesquita além do prestígio social traz a prática dessa virtude, pois anexo à mesquita pode haver a construção de edifícios beneficentes, como escolas, hospitais e refeitórios, sendo que esses espaços também contam com elementos característicos das construções das mesquitas, como cúpulas, arcos, decoração com arabescos e caligrafia. Às vezes o mausoléu do benfeitor também é feito nas imediações. Para homenagear o construtor, pode ser feito um portal ornamentado na entrada da mesquita em tributo o patrono, pedindo as bênçãos divinas. A Figura 6 traz ilustrações destes exemplos. 
Figura 6: Pátio externo e Fonte, Mesquita do Sultão Hassan (A); Pátio externo e Fonte, Yeni Cami (B); Mesquita Real de Lahore, (C); Cúpulas, Mesquita Sheik Zayed (D); Edifícios anexos, Mesquita de Solimão (E); Mausoléu de Ahmad Yasawi (F).

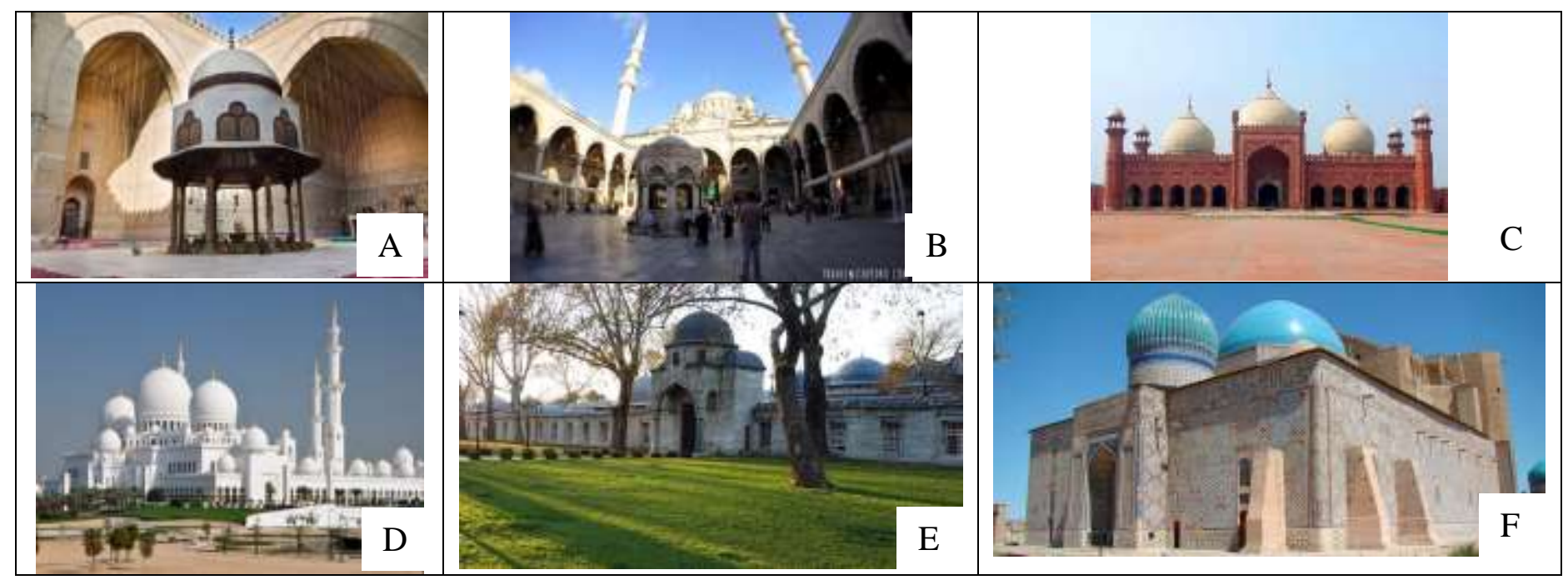

Fonte: Lugares da Religião (2021); Travel with Pedro (2021); Viagem e Turismo (2017); Viagem e Turismo (2017); Viagem e Turismo (2017); :Khanacademy (2021); Rodrigues (2021).

A Figura 6 traz exemplos de fontes (A e B), sempre inseridas no pátio externo e na área central, em que se pode observar arcos e colunas, minaretes; cúpulas (C e D) de formatos e quantidades variadas; edifícios adjacentes às mesquitas (E e F) com elementos característicos da arquitetura árabe.

Quanto aos elementos decorativos não se vislumbra altares ou imagens nas mesquitas, como ocorre no cristianismo. É proibida a reprodução da imagem de Alá, de Maomé ou de figuras humana ou animal dentro das mesquitas. Como ornamento, os muçulmanos usam as artes abstratas, arabescos, rendilhados, motivos geométricos, caligrafia, tapeçaria ornamentada criando um ambiente rico, com detalhes surpreendentes e de encher os olhos.

Arabescos podem ser inspirados em motivos vegetais, geométricos e epigráficos. $\mathrm{O}$ motivo vegetal foi o primeiro a surgir e provém de objetos decorativos menores, tendo origem na economia agrícola. O motivo geométrico utiliza figuras geométricas complexas, como o polígono, fazendo o arremate com folhas e frutos. Já o motivo epigráfico utiliza a grafia decorativa, com versos do Alcorão, alternando faixas escritas com os outros motivos. É comum encontrar a mistura dos três estilos em um único local. Estas decorações podem ser encontradas em azulejos decorados, outro elemento bastante característico da cultura islâmica. Segundo Wladimir Wagner Rodrigues (2021) "Para os Muçulmanos, essas formas decorativas em conjunto, constituem um padrão infinito que se estende para além do mundo visível e material. Para muitos no mundo Islâmico, tais formas simbolizam o infinito, e por conseguinte, a natureza abrangente da criação do Deus único (Alá)”.

A tapeçaria está presente na vida cotidiana dos muçulmanos, sendo utilizado como almofada, travesseiro e cama, hábitos herdados da vida nômade (Ande, 2013). É uma tradição cultural tear tapetes à mão, como os tradicionais tapetes turcos, feitos de lã, algodão e seda pura, apresentam uma imensa variedade de cores, texturas e estampas a depender da região. Para a religião ele é imprescindível, durante as orações os fiéis devem estar posicionados sob um tapete. Na maioria das mesquitas a sala de orações é forrada com imensos tapetes (que não são carpetes), mas quando não é possível, como no caso da Grande Mesquita de Meca, cada pessoa leva o seu tapete e se debruça sobre ele durante a oração.

A caligrafia é uma importante forma de expressão das artes islâmicas. É considerada um meio de comunicação direto entre Alá e os homens, sendo reputada como um tesouro inestimável por todos os muçulmanos, e sua compreensão é essencial para o entendimento do pensamento divino. O ofício da caligrafia exige habilidade e preciosismo, buscando sempre a 
perfeição, uma vez que representa a materialização da palavra de Deus, através da representação de trechos do Alcorão, que é utilizado como decoração nas mesquitas, em residências e em objetos (Ande, 2013). Estes trechos possuem o mesmo poder persuasivo que as imagens nas igrejas cristãs. A forma da escrita é ritmada e sua leitura se assemelha a sons, como se fosse uma poesia visual. Segundo Ande, a mensagem enviada por Deus encontrou na mesquita seu lugar natural. A seguir exemplifica-se estes elementos com imagens:

Figura 7: Elementos decorativos - Masjed-e Jameh-ye Atigh (A), Cúpula da Rocha (B), Tapeçaria da Mesquita Azul (C), Caligrafia na Mesquita Azul (D).

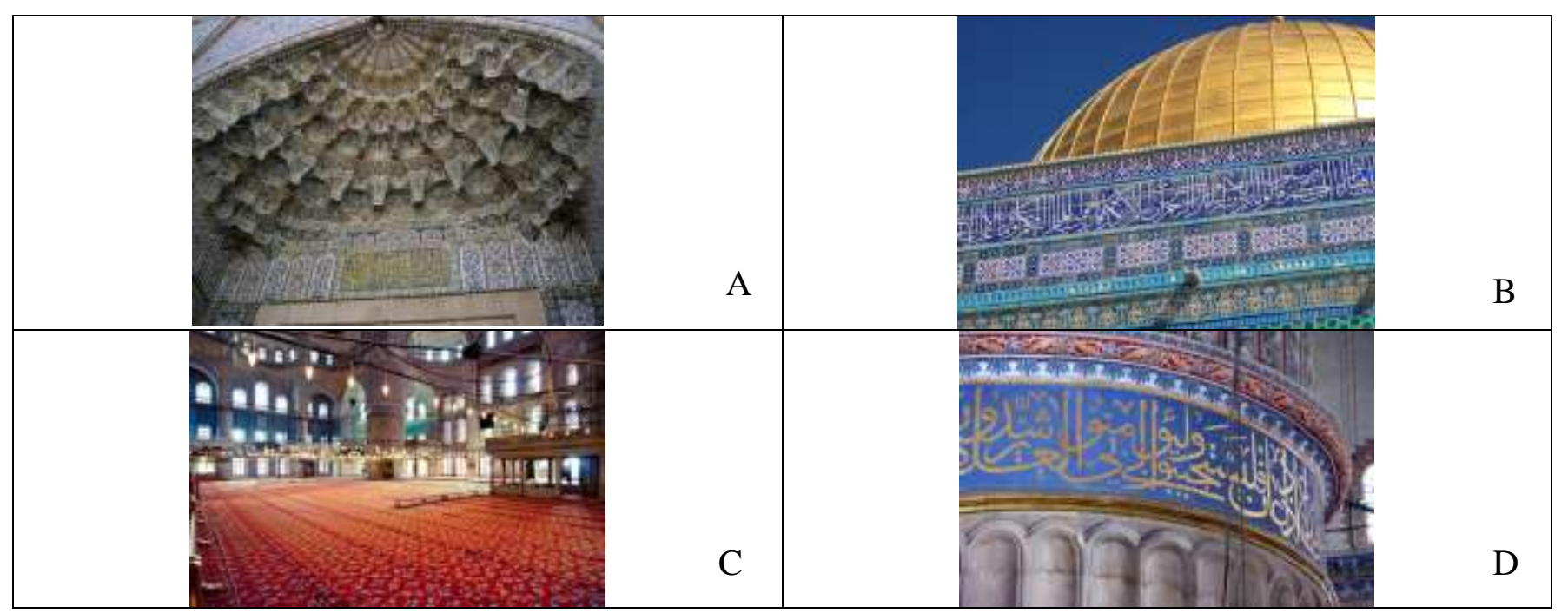

Fonte: Piccini, (2021), Rodrigues, (2021), Sultanahmetcamii, (2021), Sultanahmetcamii, (2021).

Diante do exposto há de fato uma arquitetura, ou pelo menos, elementos típicos característicos das mesquitas que são determinados pela religião, marcando a paisagem urbana das cidades com influências culturais árabes, entretanto, percebe-se que essa influência não se restringe a arquitetura religiosa desses povos. Entre os países muçulmanos existem os estados teocráticos e os seculares, que em maior ou em menor grau, apresentam algum ponto de simbiose entre religião/legislação/Estado. Dentro das mesquitas, ainda hoje ocorrem atos políticos, com o intuito de dar maior legitimidade aos governantes, através de sermões (o que nem sempre é visto com bons olhos por alguns grupos religiosos). Assim, pode ser observado que a arquitetura islâmica ultrapassa a questão da construção, do abrigo, sendo utilizada como um meio para servir à devoção. Naquela sociedade que vive de forma tão intensa a religião, não há como separar as "coisas do mundo" e as "coisas sagradas", tudo se encontra em harmonia. Nesse sentido, o site islamiocity.org traz a seguinte reflexão:

A arquitetura islâmica só pode existir sob a égide das percepções islâmicas de Deus, homem, natureza, vida, morte e a outra vida. Assim, a arquitetura islâmica seria as instalações e, ao mesmo tempo, um locus físico de atualização da mensagem islâmica. Praticamente, a arquitetura islâmica representa a religião do Islã que foi traduzida para a realidade pelas mãos dos muçulmanos. Também representa a identidade da cultura e civilização islâmicas (Islamiocity, 2021).

Dessa forma, a forte presença da religião acaba por fazer com que os elementos arquitetônicos característicos das mesquitas possam ser observados em outras construções, como nas casas muçulmanas, monumentos nas vias públicas, entre outros, demonstrando que estes elementos não são exclusivos do templo religioso, mas comum a toda a cultura islâmica. Os pátios, por exemplo, são frequentemente vistos em habitações árabes e as cúpulas em uma infinidade de edificações, inclusive em monumentos (Figura 8). 
Figura 8: Pátio com fonte em uma casa árabe (A) e Monumento com cúpula em via pública (B).

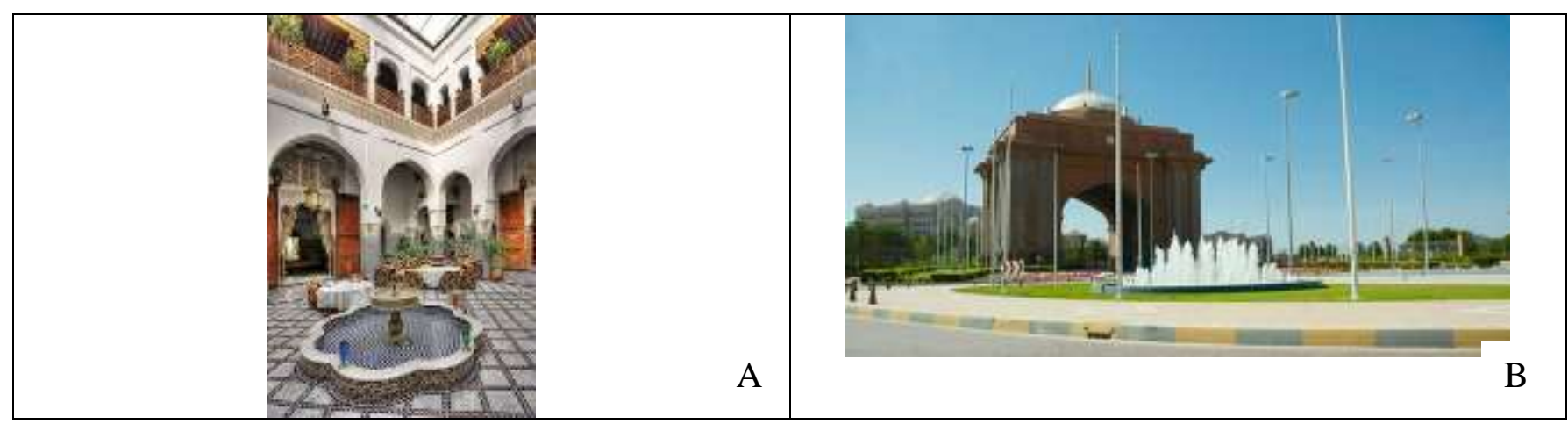

Fonte: Casa e Construção, (2021); Smiles, (2021).

Na Figura 8 apresenta-se uma casa árabe (A), que contém diversos elementos da arquitetura islâmica: pátio interno com fonte, arcos, guarda corpo em treliça de madeira, decoração das colunas e do piso com motivos geométricos. O monumento em via pública (B) apresenta cúpula, arco, colunas trabalhadas, está inserido em um local com fontes de água, elementos valorizados pelos povos árabes.

\subsection{A influência da arquitetura árabe no Brasil}

A Expansão Árabe difundiu sua cultura em grande parte do mundo, resultando numa intensa troca de conhecimento entre diversos povos, com respeito aos costumes locais e aos povos colonizados. Os muçulmanos tiveram uma convivência pacífica com os cristãos, pois os governantes islâmicos demonstraram grande tolerância com os povos locais, que passaram até a dividir os mesmos templos, sendo as sextas feiras reservadas aos muçulmanos, os sábados aos judeus e os domingos aos cristãos (Valjalo, 2015).

Como a colonização do Brasil foi feita pelos portugueses percebe-se a presença de elementos da arquitetura islâmica trazidos pelos moçárabes ${ }^{6}$, que reuniram técnicas construtivas, como o uso do adobe, taipa e tijolo cozido, que tiveram de ser adaptadas a realidade local - como a utilização de beirais nos telhados para a proteção contra as águas das chuvas (o que é raro de ocorrer no deserto). Também houve um intenso movimento de imigração de sírios e libaneses para o país entre o final do século XIX e o início do século XX (Icarabe, 2006), o que acaba por ratificar esta influência.

A pesquisadora Lygia Rocco, aponta que a influência da arquitetura árabe no país teve início no Nordeste e se expandiu para a região de São Paulo. Afirma que vários elementos usados na arquitetura brasileira, como o uso de muxarabis, balcões, rótulas e azulejaria podem ser considerados elementos herdados da cultura árabe (Icarabe, 2006). Esse uso pode ser visto em obras como a Casa de Chica da Silva, em Diamantina.

Elementos como os azulejos podem ser vistos em diversas obras espelhadas pelo país, com destaque para as de Cândido Portinari, presente nas edificações modernistas do Conjunto Moderno da Pampulha, em especial na Igreja de São Francisco de Assis, que foi declarada Patrimônio Mundial pela Unesco em 2016 (Portal Iphan, 2016) e no Palácio Gustavo Capanema no Rio de Janeiro, conforme se observa na Figura 9.

\footnotetext{
${ }^{6}$ Os espanhóis muçulmanos batizados sob as ordens dos Reis Católicos (García-Pardo 2009, p.458).
} 
Figura 9: Influência da Arquitetura Islâmica no Brasil - Casa de Chica da Silva (A), Igreja de São Francisco de Assis (B), Palácio Gustavo Capanema (C).

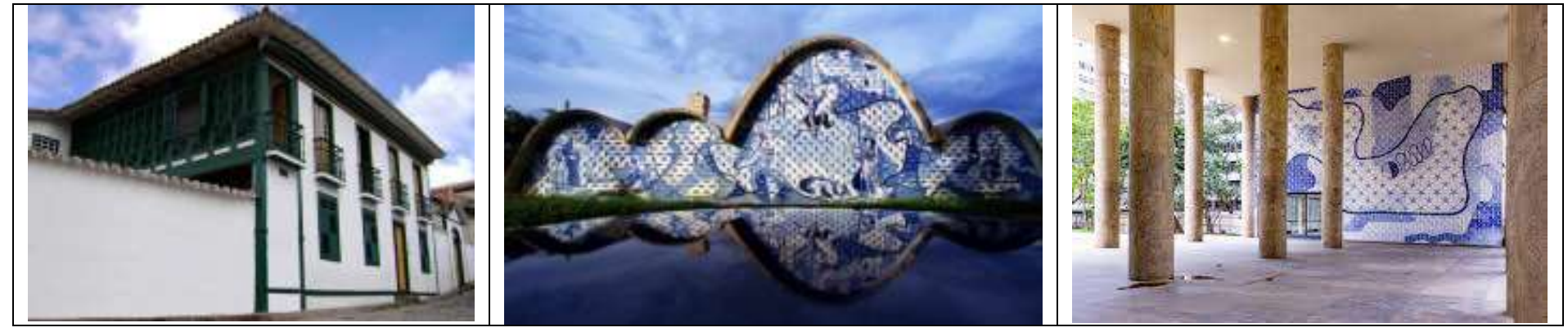

Fonte: Portal IPHAN, (2021); Revista Projeto, (2021), Jornal do Brasil (2018).

Na Casa. Chica da Silva, "Destaca-se particularmente, no conjunto da casa, a bela varanda lateral, inteiramente composta por painéis treliçados, almofadados e com balaústres, atestando a influência mourisca na arquitetura brasileira" (Portal Iphan, 2021). Os azulejos presentes nas obras clássicas brasileiras também são herança da arquitetura árabe.

\section{Conclusão}

A cultura islâmica é um terreno pouco explorado no Brasil, porém, trata-se de um tema atual e relevante diante do crescimento exponencial da religião no cenário mundial. Com a previsão de se tornar a maior religião do mundo ainda neste século, percebe-se que a influência islâmica poderá ser muito mais marcante no Brasil, bem como no mundo. Destaca-se, por essa razão, a necessidade de ter em mente o relativismo cultural, para que se possa entender a cultura pelo olhar do outro, sem preconceitos que impeçam a aproximação e o convívio pacífico entre grupos diferentes.

Dessa forma, é importante assimilar a influência da religião na arquitetura islâmica como fator determinante nas construções, estabelecendo que a fé é o elemento primordial em todas as esferas da vida cotidiana dos muçulmanos e que a arquitetura é mais um meio para alcançar os seus preceitos. E que a religião acaba por determinar elementos característicos marcantes da arquitetura das mesquitas, mas também da arquitetura e urbanismos seculares, que acabam, por sua vez, influenciando culturalmente outras sociedades, como ocorreu no Brasil.

Considerando que os elementos característicos das mesquitas se repetem em outras construções, novos estudos que analisem o nível de influência da religião ou que se aprofundem no reconhecimento desses elementos em outros tipos de edificações dos países árabes podem expandir os conhecimentos aqui apresentados e evidenciar ainda mais como a religião atua psicológica e fisicamente nos países islâmicos. Pesquisas que investiguem a presença da arquitetura árabe, dos elementos característicos dessa arquitetura ou de sua influência na arquitetura e urbanismo de outros países também podem ampliar os achados da pesquisa aqui desenvolvida.

\section{Referências}

Andes, E. \& Lemos, S. (2013). Arte islâmica. Instituto Calis.

Araújo, D. (2019) Islamismo: como é a religião muçulmana? Website Politize. https://www.politize.com.br/islamismo-como-e-a-religiao-muculmana/

Archdaily. (2021). A importância arquitetônica, cultural e, religiosa-dos-minaaretes. Website Archdaily. https://www.archdaily.com.br/br/968174/aimportancia-arquitetonica-cultural-e-religiosa-dos-minaretes?utm_medium=email\&utm_source=ArchDaily\%20Brasil\&kth=5,222,327

Baratto, R. (2016). 121 Definições de Arquitetura. Website Archdaily. https://www.archdaily.com.br/br/800699/121-definicoes-de-arquitetura

Britannica. (2021). Great Mosque of Mecca. Website Britannica. https://www.britannica.com/topic/Great-Mosque-of-Mecca 
Research, Society and Development, v. 10, n. 14, e09101421679, 2021

(CC BY 4.0) | ISSN 2525-3409 | DOI: http://dx.doi.org/10.33448/rsd-v10i14.21679

Canossa, C. (2020). Como é uma peregrinação para Meca? Website Super Interessante. https://super.abril.com.br/mundo-estranho/como-e-uma-peregrinacaopara-mecal

Casa e Construção. (2021). Casas Árabes. Website Casa e Construção. https://casaeconstrucao.org/projetos/casas-arabes/rabes/

Clitmenestra. (2013). Mesquita-Yeni-Cami-em-Istambul. Website Clitmenestra. http://clitmenestra.blogspot.com/2013/04/mesquita-yeni-cami-emistambul.html.

Daflon, R. (2018). As mais belas fachadas do Brasil. Website Jornal do Brasil. https://www.jb.com.br/rio/2018/09/7577-as-mais-belas-fachadas-do-brasil.html

Epochtimes. (2021). Masjid al-Haram, um dos lugares mais sagrados para os muçulmanos. Website Epochtimes. https://www.epochtimes.com.br/masjid-alharam-lugares-mais-sagrado-muculmanos/

Estado de Minas. (2020). Descriminados por nova lei, islâmicos criticam intolerância na Índia. Website Jornal Estado de Minas. https://www.em.com.br/app/noticia/economia/2020/02/09/internas_economia,1120559/discriminados-por-nova-lei-islamicos-criticam-intolerancia-naindia.shtml

Fernandes, C. (2021). Expansão islâmica. Website Mundo Educacao. https://mundoeducacao.uol.com.br/historiageral/expansao-islamica.htm

García-Pardo, R. (2009). Arte e arquitetura mourisca e mudéjar na Espanha medieval e na américa. Revista do Corpo Discente do Programa de Pós Graduação em História da UFRGS, 2(2), 458-463

Gil, A. (2009). Como elaborar projetos de pesquisa. Atlas.

Glancey, J. (2001). A História da Arquitetura. Edições Loyola. Website Mizanzuk. https://mizanzuk.files.wordpress.com/2018/02/glancey-e28093-historiaarquitetura.pdf

Gramatica. (2021). Etimologia de "arquitetura". Website Gramatica. https://www.gramatica.net.br/origem-das-palavras/etimologia-de-arquitetura/

Guia Viagem. (2021). Isfahan Grande Mesquita Mesquita Jameh. Website Guia Viagem. https://www.guiaviagem.org/isfahan-grande-mesquita-mesquitajameh/\#

Icarabe. (2006). Arquitetura árabe chega ao Brasil nas naus portuguesas e depois com imigração sírio-libanesa. Website Icarabe. https://icarabe.org/noticias/arquitetura-arabe-chega-ao-brasil-nas-naus-portuguesas-e-depois

Iphan. (2016). Conjunto Moderno da Pampulha é mais novo Patrimônio Mundial. Website Iphan. http://portal.iphan.gov.br/noticias/detalhes/3689/conjuntomoderno-da-pampulha-e-mais-novo-patrimoni

Iphan. (2021). Escritório técnico em Diamantina: Casa da Chica da Silva. Website Iphan. http://portal.iphan.gov.br/mg/pagina/detalhes/1278

Instagram. (2021). Imagem interior da Masjid al-Haram. Website Instagram. https://www.instagram.com/p/CTq5egVoiiP/?utm_medium=share_sheet

Wikiarquitetura. (2021). Mezquita Sheik Zayed. Website Wikiarquitetura. https://es.wikiarquitectura.com/edificio/mezquita-sheikh-zayed/

Khanacademy. (2021). Understanding-Religion-art/islam/a/introduction-to-mosque-architecture. Website Khanacademy. https://pt.khanacademy.org/hu manities/a pproaches-to-art-history/understanding-religion-art/islam/a/introduction-to-mosque-architecture.

Lugares da Religião. (2021). Arquiteturas Religiosas. Website Arquiteturas Religiosas. https://sites.google.com/site/lugaresdareligiao/arquiteturasreligiosas/ai5

Mariani, C. \& Kus, A. (2019). Arquitetura Islâmica nas mesquitas e seus efeitos sobre os adeptos. Revista de Estudos da Religião 19(1) (2019). Religio e suas Arquiteturas. https://doi.org/10.23925/1677-1222.2018vol19i1a9

Minayo, M. (2008). O desafio do conhecimento. Hucitec.

Novelo, C. (2017). Islamismo é a crença que mais cresce no mundo. Website Vestibular.Uol. https://vestibular.uol.com.br/resumo-dasdisciplinas/atualidades/islamismo-e-a-religiao-que-mais-cresce-no-mundo-carolina-cunha.htm

Omer, S. (2016). The History of al-Masjid al-Haram and the History of Islamic Architecture. Website Islamiocity https://www.islamiocity.org/9838/thehistory-of-al-masjid-al-haram-and-the-history-of-islamic-architecture/

Piccini, A. (2021). A arquitetura como resultado do processo histórico e cultural no Irã. Revista USP (103) 123-138. https://doi.org/10.11606/issn.23169036.v0i103p123-138

Revista Projeto. (2016). Pampulha é declarada Patrimônio Mundial da Humanidade. Website Revista Projeto. https://revistaprojeto.com.br/noticias/pampulhae-declarada-patrimonio-mundial-da-humanidade/

Rocco, L. (2008). A Mesquita de Ibn Tūlūn com Representação da Herança Arquitetônica Árabe. Dissertação (Mestrado). Universidade de São Paulo. 10.11606/D.8.2009.tde-23042009-122942

Rodrigues. W. (2021). Curso História da Arte - Módulo I - Idade Antiga ao Renascimento. As origens das tradições estéticas. 8 Encontro - Arte Islâmica. Website TRF3. https://www.trf3.jus.br/documentos/emag/Cursos/435_-_Historia_da_Arte_-_Modulo_I_-_Idade_Antiga/8o_Encontro/09_HA_ Arte_Isla mica.pdf

Sanchez, G. (2009). Sharia, a lei islâmica, rege tudo na vida do muçulmano. Website G1. https://g1.globo.com/Noticias/Mundo/0,,MUL1289629-5602,00SHARIA+A+LEI+ISLAMICA+REGE+TUDO+NA+VIDA+DO+MUCULMANO.html 
Research, Society and Development, v. 10, n. 14, e09101421679, 2021

(CC BY 4.0) | ISSN 2525-3409 | DOI: http://dx.doi.org/10.33448/rsd-v10i14.21679

Santos, J. (2013). Introdução à Arquitetura Islâmica. Anais do $1^{\circ}$ Simpósio Sudeste da ABHR-Diversidades e Intolerâncias Religiosas 1., 47-54.

Santos, J. (2006). O que é cultura. Braziliense.

Seara, M. (2016). A casa islâmica como linguagem do ser - (des)continuidades. Projetos de habitação premiados pelo Aga Khan para arquitetura. 2015/2016.

Universidade do Porto, 55-69.

Smiles. (2021). Maravilhas do Oriente Médio. Website Smiles. https://www.smiles.com.br/dicas-smiles/viajo-logo-existo/maravilhas-do-oriente-medio.

Sultanhmetcamii. (2021). Sedefkar-Mehmed-Agha. Website Sultanhmetcamii. http://www.sultanahmetcamii.org/sedefkar-mehmed-agha/

Terra Santa Viagens. (2021). Mesquita-de-Rustem-Paxa. Website Terra Santa Viagens. https://terrasantaviagens.com.br/mesquita-de-rustem-paxa/

Toda Materia. (2021). Império Árabe. Website Toda Materia. https://www.todamateria.com.br/imperio-arabe/.

Todorov, T. (2010). O medo dos bárbaros. Para além do choque das civilizações. Editora Vozes.

Unitur. (2021). Conheça a história e as curiosidades da majestosa Mesquita Azul em Istambul. Website Unitur. https://www.unitur.com.br/conheca-a-historiae-as-curiosidades-da-majestosa-mesquita-azul/.

Viator. (2021). Grande Mesquita Sheik Zayed Tour de Dubai. Website Viator. https://www.viator.com/pt-BR/tours/Dubai/Sheikh-Zayed-Grand-Mosque-TourFrom-Dubai/d828-136681P9.

Viggiano, G. (2019). Crenças de ateus e agnósticos: relatório traz dados sobre brasileiros sem religião. Revista Galileu. Website Revista Galileu https://revistagalileu.globo.com/Sociedade/noticia/2019/07/crencas-de-ateus-e-agnosticos-relatorio-traz-dados-sobre-brasileiros-sem-religiao.html

Zimmermann, A. (2021). TH2 A Arquitetura Muçulmana. Website Puc Goias. http://professor.pucgoias.edu.br/sitedocente/admin/arquivosUploa d/17497/material/aula\%2006\%20-\%20arquitetura\%20islamica.pdf 